\title{
Pancreatico-psoas fistula: a rare complication of acute pancreatitis
}

\author{
Sunita Deshmukh, Keith Roberts, Gareth Morris-Stiff, Andrew Smith \\ Department of HPB Surgery, Leeds Teaching Hospitals NHS Trust, Leeds, UK
}

Correspondence to Dr Sunita Deshmukh, sunitadeshmukh@doctors.org.uk

\section{Summary}

The authors present a case of post endoscopic retrograde cholangio-pancreatography acute pancreatitis complicated by a pancreaticopsoas fistula, as well as reviewing similar previously published cases. The patient had a fluctuating clinical course over 4 months, developing multiple life-threatening complications including portal vein thrombosis, gastrointestinal bleeding, aspiration pneumonia and acute kidney injury on a background of chronic kidney disease. The authors followed the long-held surgical principle of draining sepsis and avoiding surgical intervention. The fistula dried up with conservative management and time also allowed portal venous collateral formation with resolution of his ascites.

\section{BACKGROUND}

Acute pancreatitis is most often a mild, self-limiting inflammatory condition but can cause multi-organ failure and death. Both acute and chronic pancreatitis can lead to pancreatic duct disruption with resultant pseudocyst formation or pancreatic ascites. Pancreatic pseudocysts can be complicated by infection, bleeding, compression of adjacent viscera, involvement of local vascular structures and fistula formation. Very rarely pancreatic secretions can track posteriorly into the retroperitoneum along the psoas muscle, and can present with an abscess or fistula in the thigh.

This case demonstrates the development of a retroperitoneal pancreatic fistula with an abscess in the right thigh, on the background of an already complex acute pancreatitis. The presented case exemplifies and highlights the need to consider important clinical challenges in diagnostic and therapeutic decision-making processes.

\section{CASE PRESENTATION}

A 70-year-old man was transferred to our unit 2 weeks after developing acute necrotising pancreatitis following an endoscopic retrograde cholangio-pancreatography for choledocholithiasis. Initial cross-sectional imaging demonstrated a large complex multiloculated peri-pancreatic acute fluid collection in the lesser sac extending up into the hilum of the liver. The patient's clinical status initially improved and the collection appeared to be resolving. $\mathrm{He}$ was maintaining adequate oral nutrition and hydration, and was discharged home. He re-presented with gastric outlet obstruction and tense ascites. Repeat imaging demonstrated that the complex pseudocyst remained. The portal vein was now effaced by the pseudocyst and there was associated thrombosis. There was also extensive ascites which was aspirated and sent for analysis. This was negative for amylase and had the biochemical features of
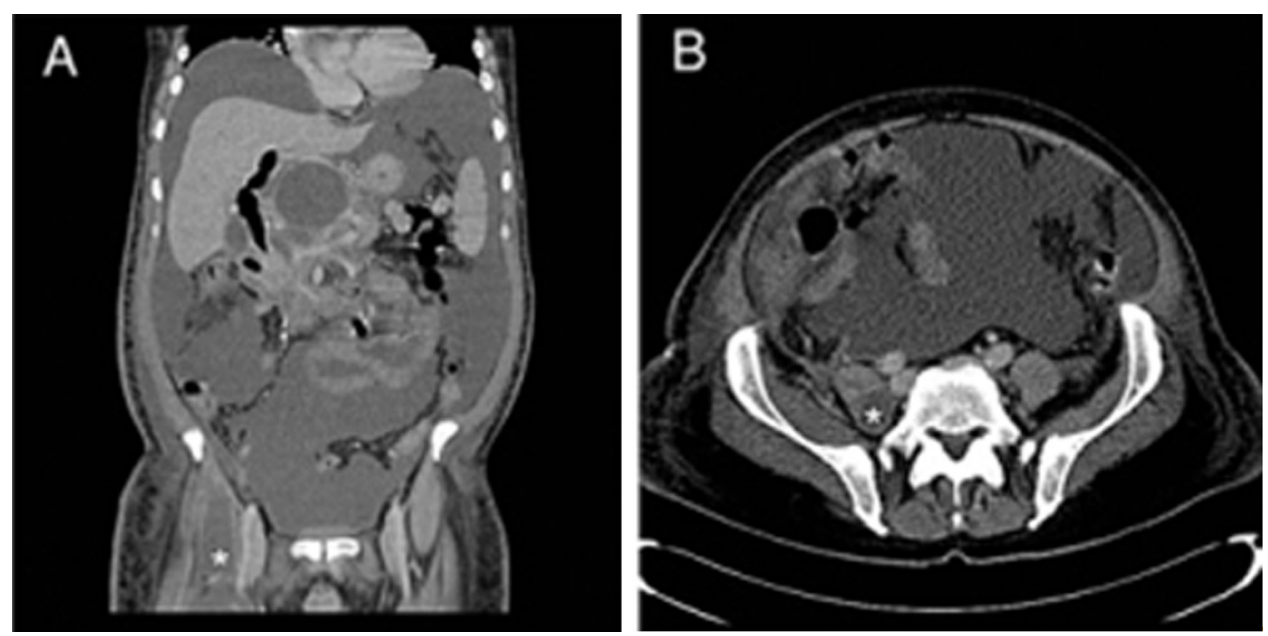

Figure 1 (A) demonstrates the site of the fistula as indicated by the asterisk, lateral to the femoral artery. Note the large volume ascites which on no occasion had raised amylase levels. (B) demonstrates the fistula track as indicated by the asterisk, adjacent to the psoas muscle. 


\section{BMJ Case Reports}

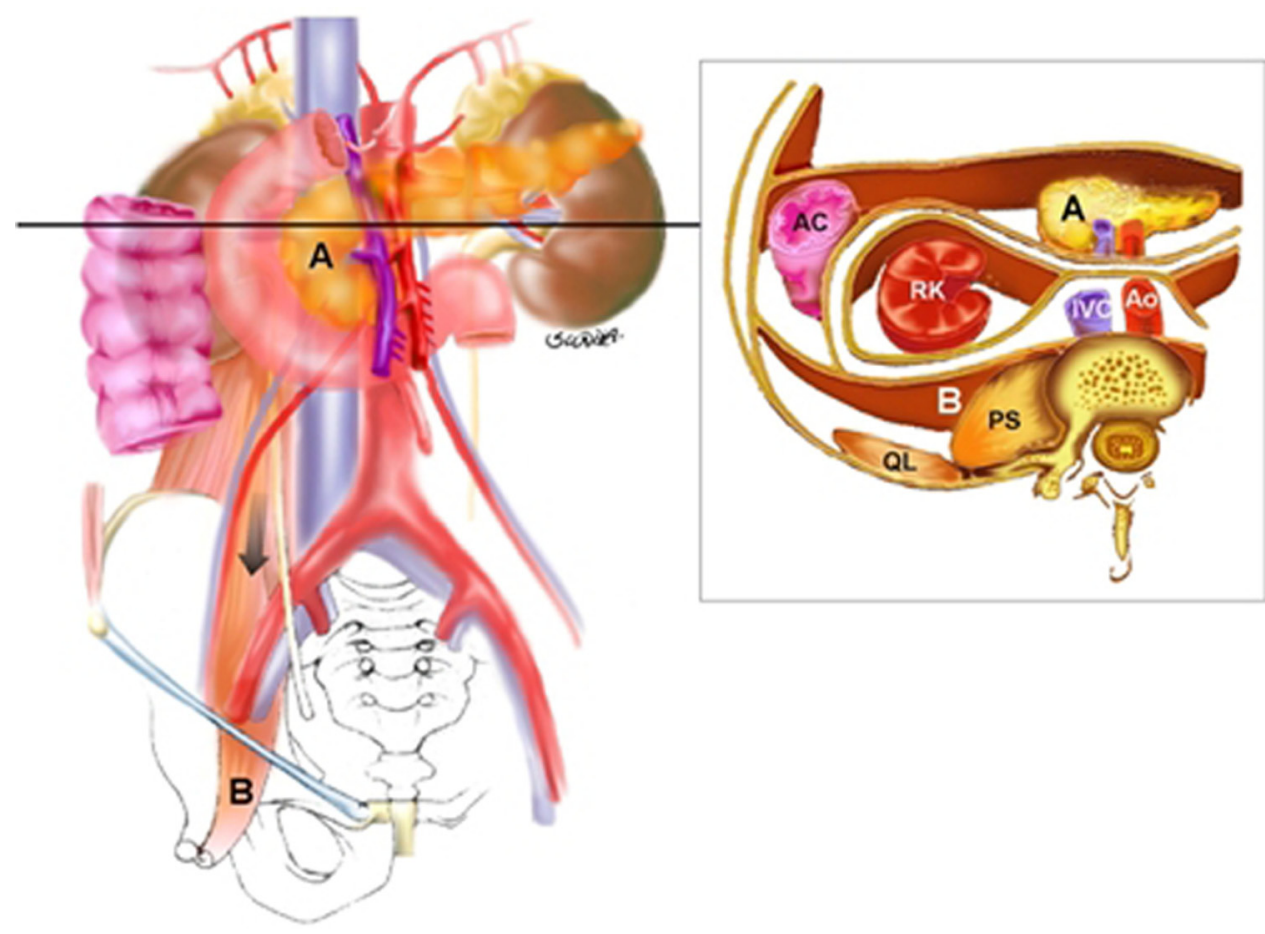

Figure 2 Proteolytic fluid from a pancreatic pseduocyst can extend into the iliopsoas compartment beneath the inguinal ligament; this path of spread occurs via the inferior portion of the anterior pararenal space, which communicates freely with the posterior pararenal space. ${ }^{19}$

Table 1 Summary of previously reported cases of pancreatico-psoas fistula ${ }^{10-18}$

\begin{tabular}{|c|c|c|c|c|c|}
\hline Age, sex & Presenting features & Imaging findings & Underlying disease/condition & Management & Reference \\
\hline \multirow[t]{2}{*}{$49, M$} & $\begin{array}{l}\text { Right groin swelling and } \\
\text { pain radiating to right } \\
\text { testicle, in keeping with } \\
\text { incarcerated inguinal hernia }\end{array}$ & $\begin{array}{l}\text { Direct communication between head of } \\
\text { pancreas and right inguinal incision }\end{array}$ & $\begin{array}{l}\text { Chronic pancreatitis with history } \\
\text { of excess alcohol intake }\end{array}$ & $\begin{array}{l}\text { Auto decompression of } \\
\text { pseudocyst after biopsy }\end{array}$ & $\begin{array}{l}\text { Salvo and } \\
\text { Nematolahi }^{10}\end{array}$ \\
\hline & $\begin{array}{l}\text { Left inguinal mass with } \\
\text { features in keeping with } \\
\text { incarcerated inguinal hernia }\end{array}$ & $\begin{array}{l}\text { Communication between pancreas and left } \\
\text { inguinal region }\end{array}$ & $\begin{array}{l}\text { Recent pancreatitis with history } \\
\text { of excess alcohol intake }\end{array}$ & Surgical drainage & Lombrozo et a/ $/^{11}$ \\
\hline $62, \mathrm{M}$ & Left thigh swelling & $\begin{array}{l}\text { Pancreatic pseudocyst with extension } \\
\text { into left lower quadrant of abdomen, left } \\
\text { hemipelvis, left gluteal region and left thigh } \\
\text { up to the knee }\end{array}$ & $\begin{array}{l}\text { Recent ( } 1 \text { month earlier) acute } \\
\text { gall stone pancreatitis }\end{array}$ & $\begin{array}{l}\text { Surgical drainage through } \\
\text { lesser sac and left lower } \\
\text { quadrant }\end{array}$ & Lye et $a l^{13}$ \\
\hline $42, \mathrm{~F}$ & $\begin{array}{l}\text { Left thigh swelling and pain } \\
\text { with bluish discolouration } \\
\text { near groin }\end{array}$ & $\begin{array}{l}\text { Diffuse pancreatic calcification and } \\
\text { multiple radiolucent areas in an enlarged } \\
\text { left psoas muscle.Communication between } \\
\text { left psoas sheath and pancreatic bed } \\
\text { discovered at laparotomy }\end{array}$ & $\begin{array}{l}\text { Chronic pancreatitis with history } \\
\text { of excess alcohol intake }\end{array}$ & $\begin{array}{l}\text { Splenectomy and distal } \\
\text { pancreatectomy followed } \\
\text { by surgical drainage of } \\
\text { postop left subphrenic } \\
\text { fluid collection }\end{array}$ & Alrabeeah et $a l^{12}$ \\
\hline $49, M$ & $\begin{array}{l}\text { Left hip pain and reduced } \\
\text { range of movement }\end{array}$ & $\begin{array}{l}\text { Peri-pancreatic collection communicating } \\
\text { with left-sided intrapsoas pseudocyst }\end{array}$ & $\begin{array}{l}\text { Chronic history of excess alcohol } \\
\text { intake }\end{array}$ & Percutaneous drainage & Alvarez-Castells ${ }^{14}$ \\
\hline $61, M$ & $\begin{array}{l}\text { Lower back pain, right hip } \\
\text { pain, } 12 \mathrm{~kg} \text { weight loss }\end{array}$ & $\begin{array}{l}\text { Peri-pancreatic collection (and } \\
\text { calcifications) communicating with large } \\
\text { right-sided intrapsoas fluid collection }\end{array}$ & $\begin{array}{l}\text { Chronic history of excess alcohol } \\
\text { intake, acute pancreatitis } 12 \\
\text { years previously }\end{array}$ & Percutaneous drainage & Alvarez-Castells $\mathbf{s}^{14}$ \\
\hline $42, \mathrm{M}$ & $\begin{array}{l}\text { Right inguinal swelling } \\
\text { and pain, in keeping with } \\
\text { incarcerated inguinal hernia }\end{array}$ & $\begin{array}{l}\text { Complex pancreatic pseudocyst dissecting } \\
\text { into right inguinal region, subsequent } \\
\text { pseudocysts over right retroperitoneum }\end{array}$ & $\begin{array}{l}\text { Chronic pancreatitis with history } \\
\text { of excess alcohol intake }\end{array}$ & Percutaneous drainage & Erzurum et a/ ${ }^{15}$ \\
\hline $35, \mathrm{M}$ & Right thigh swelling & $\begin{array}{l}\text { Fistula between Wirsung duct and right } \\
\text { psoas muscle }\end{array}$ & History of excess alcohol intake & Percutaneous drainage & Weber et a/ ${ }^{16}$ \\
\hline $40, M$ & $\begin{array}{l}\text { Right groin swelling and } \\
\text { abscess }\end{array}$ & $\begin{array}{l}\text { Pancreatic calicification with duct dilation } \\
\text { but no duct disruption seen. Psoas abscess } \\
\text { extending from pancreas to right groin }\end{array}$ & $\begin{array}{l}\text { Chronic pancreatitis secondary } \\
\text { to tropical pancreatitis }\end{array}$ & Percutaneous aspiration & Harish K et a $/^{17}$ \\
\hline $45, M$ & $\begin{array}{l}\text { Upper abdominal pain and } \\
\text { tender left inguinal mass }\end{array}$ & $\begin{array}{l}\text { Large pancreatic pseudocyst extending up } \\
\text { to aortic hiatus and down to left inguinal } \\
\text { region via psoas muscle, with pancreatic } \\
\text { duct dilatation and pancreatic calculi }\end{array}$ & Chronic calcifying pancreatitis & $\begin{array}{l}\text { Distal pancreatectomy } \\
\text { and longitudinal } \\
\text { pancreaticojejunostomy }\end{array}$ & Tajima et a/18 \\
\hline
\end{tabular}


a transudate. A liver biopsy was performed and demonstrated normal hepatic architecture.

\section{TREATMENT}

We adopted a conservative management policy including nutritional support via nasojejunal feeding and pharmacological optimisation of body fluid balance with spironolactone. A transjugular intrahepatic portosystemic shunt procedure was ruled out given the patient's frail clinical state and impaired renal function; it was hoped that following collateral portal venous formation, the ascites would settle. After a period of 6 weeks, the patient suddenly deteriorated with a rise in temperature and inflammatory markers. Examination revealed a hot swelling in his right thigh; CT demonstrated an extensive peri-pancreatic collection, extending via the right psoas muscle into the right thigh (figures 1 and 2) with abscess formation within the thigh. This was drained percutaneously, amylase rich (1037 IU/l) pus was aspirated, confirming a diagnosis of pancreatico-psoas fistula. The drain was left in situ until dryness. Octreotide injections, $200 \mathrm{mcg}$ three times daily, were administered. Following a brief improvement in the patient's condition, he developed further sepsis secondary to infection of the pancreatic pseudocyst, which was treated with percutaneous transgastric drainage.

\section{OUTCOME AND FOLLOW-UP}

The patient had a fluctuating clinical course over 4 months during which he developed several complications including acute upper gastrointestinal bleeding secondary to a pseudoaneurysm of the left gastric artery treated by angiographic embolisation; aspiration pneumonia requiring invasive ventilation; episodes of acute kidney injury on a background of chronic kidney disease.

Through treatment of sepsis and nutritional support the patient gradually improved with resolution of the peripancreatic inflammation, gastric outlet obstruction, renal impairment and ascites. He was discharged home fully independent.

\section{DISCUSSION}

Pancreatic pseudocysts complicate between $5 \%$ to $16 \%$ of patients with acute pancreatitis. ${ }^{1}$ Treatment is reserved for symptomatic cysts. The method of treatment depends upon patient factors, location of the cyst and whether there is debris within.

Acute fluid collections lacking a cyst wall arise early in the course of acute pancreatitis. Pseudocysts of the pancreas are localised fluid collections that present for more than 6 weeks, rich in pancreatic enzymes and surrounded by a wall of granulation tissue and extracellular matrix as opposed to true pancreatic cysts lined by epithelium. ${ }^{2} 3$

Initial diagnosis is usually achieved by imaging studies including transabdominal ultrasonography and CT scanning. CT offers high sensitivity rates of $82 \%$ to $100 \% .^{2} 3$ Endoscopic ultrasound is highly sensitive for distinguishing between different types of pancreatic cystic lesions.

The pathogenesis of pancreatic pseudocysts is related to pancreatic duct disruption with secretions typically confined to the lesser sac although they can extend cranially or caudally following anatomical planes. Pseudocysts have been reported in unusual locations including the mediastinum, ${ }^{45}$ pleura,${ }^{67}$ liver ${ }^{8}$ and scrotum. ${ }^{9}$ Few reports have described a pancreatic pseudocyst involving the psoas muscle and inguinal region. ${ }^{10-18}$ In the present case, reviewing the cross sectional imaging, the pseudocyst progressively tracked into the right retroperitoneum, anterior to the psoas and into the thigh. Its presence was only discovered when the patient presented with a right thigh abscess. This was treated with percutaneous drainage and the somatostatin analogue, octreotide.

Ten previously published cases were identified in the English language literature and were reviewed (table 1). ${ }^{10-18}$ Eight patients presented with a painful groin mass and two with hip pain. Only two cases followed a recent episode of acute severe pancreatitis with the remainder complicating chronic pancreatitis. Six cases were treated by percutaneous drainage, and the remainder with a variety of surgical interventions, of which two were for fluid collections masquerading as incarcerated inguinal herniae.

In general, decisions regarding intervention in complicated or symptomatic cases require multi-disciplinary input. We adopt a step-up approach starting with internal or external percutaneous drainage. If fistula output fails to resolve, endoscopic insertion of a pancreatic duct stent is attempted. In managing cases of complex pancreaticopleural fistula in our unit, pancreatic duct stenting has been successful in treating cases refractory to percutaneous drainage. ${ }^{6}$ Open surgical intervention is ideally avoided due to additional inflammatory burden, and higher morbidity and mortality compared with endoscopic and minimally invasive therapeutic drainage techniques. ${ }^{2}$

\section{Learning points}

- Pancreatitis is commonly complicated by pancreatic pseudocysts which can result in fistula formation.

- In the pathogenesis of pancreatic pseudocysts, secretions may extend to unusual anatomical locations, presenting with clinical features which may be misinterpreted unless there is a high index of clinical suspicion.

- CT is routinely the diagnostic imaging modality of choice for pancreatic pseudocysts.

- Management of pancreatic pseudocysts varies with the patient's clinical condition and local expertise, requiring multi-disciplinary input.

Acknowledgements Dr Maria Sheridan, Consultant Radiologist, St James' University Hospital, Leeds Teaching Hospitals NHS Trust

\section{Competing interests None.}

Patient consent Not obtained.

\section{REFERENCES}

1. Aghdassi AA, Mayerle J, Kraft M, et al. Pancreatic pseudocysts-when and how to treat? HPB (Oxford) 2006;8:432-41.

2. Lerch MM, Stier A, Wahnschaffe U, et al. Pancreatic pseudocysts: observation, endoscopic drainage, or resection? Dtsch Arztebl Int 2009; 106:614-21.

3. Habashi S, Draganov PV. Pancreatic pseudocyst. World J Gastroenterol 2009; 15:38-47.

4. Drescher R, Köster 0, Lukas C. Mediastinal pancreatic pseudocyst with isolated thoracic symptoms: a case report. J Med Case Reports 2008;2:180.

5. Gupta R, Munoz JC, Garg P, et al. Mediastinal pancreatic pseudocyst-a case report and review of the literature. MedGenMed 2007;9:8. 


\section{BMJ Case Reports}

6. Khan AZ, Ching R, Morris-Stiff G, et al. Pleuropancreatic fistulae: specialist center management. J Gastrointest Surg 2009;13:354-8.

7. Sut M, Gray R, Ramachandran M, et al. Pancreaticopleural fistula: a rare complication of ERCP-induced pancreatitis. Ulster Med J 2009;78:185-6.

8. Mofredj A, Cadranel JF, Dautreaux M, et al. Pancreatic pseudocyst located in the liver: a case report and literature review. J Clin Gastroenterol 2000;30:81-3.

9. Ballestero DR, Aguilera TC, Gutierrez BJL, et al. Scrotal mass as result of a pancreatic pseudocyst extension. Actas Urol Esp 2008;32:261-4.

10. Salvo AF, Nematolahi H. Distant dissection of a pancreatic pseudocyst into the right groin. Am J Surg 1973;126:430-2.

11. Lombrozo R, Wolloch $Y$, Dintsman M. Retroperitoneal dissection of a pancreatic pseudocyst to the left inguinal region. Isr J Med Sci 1977:13:309-12.

12. Alrabeeah AA, Cattral $M$, Siegenberg J. Unusual presentation of a pancreatic pseudocyst: a case report. Can J Surg 1987;30:281-2.
13. Lye DJ, Stark RH, Cullen GM, et al. Ruptured pancreatic pseudocyst: extension into the thigh. AJR Am J Roentgenol 1987;149:937-8.

14. Alvarez-Castells A, Comet R, Alvarez-Moro J, et al. Psoas muscle pancreatic pseudocyst: CT-US diagnosis and percutaneous drainage. Gastrointest Radiol 1989:14:229-32.

15. Erzurum VZ, Obermeyer R, Chung D. Pancreatic pseudocyst masquerading as an incarcerated inguinal hernia. South Med J 2000;93:221-2.

16. Weber AG, Perez T, Bouche 0, et al. [Fistula between Wirsung and psoas muscle]. Ann Chir 2005;130:487-90.

17. Harish K . Thomas V, Kumar S, et al. Infected pseudocyst in tropical pancreatitis presenting as psoas abscess. Indian J Gastroenterol 2006;25:260-1.

18. Tajima $\mathbf{Y}$, Mishima T, Kuroki T, et al. Huge pancreatic pseudocyst migrating to the psoas muscle and inguinal region. Surgery 2009;145:341-2.

19. Deshmukh SR, Wong NWK. The Renal System Explained: An Illustrated Core Text. Chapter 3. Nottingham: Nottingham University Press 2009.

This pdf has been created automatically from the final edited text and images.

Copyright 2012 BMJ Publishing Group. All rights reserved. For permission to reuse any of this content visit http://group.bmj.com/group/rights-licensing/permissions.

BMJ Case Report Fellows may re-use this article for personal use and teaching without any further permission.

Please cite this article as follows (you will need to access the article online to obtain the date of publication).

Deshmukh S, Roberts K, Morris-Stiff G, Smith A. Pancreatico-psoas fistula: a rare complication of acute pancreatitis. BMJ Case Reports 2012;

10.1136/bcr.11.2011.5083, Published XXX

Become a Fellow of BMJ Case Reports today and you can:

- Submit as many cases as you like

- Enjoy fast sympathetic peer review and rapid publication of accepted articles

- Access all the published articles

- Re-use any of the published material for personal use and teaching without further permission

For information on Institutional Fellowships contact consortiasales@bmjgroup.com

Visit casereports.bmj.com for more articles like this and to become a Fellow 